\title{
PENGARUH SUPLEMENTASI VITAMIN C DAN JARAK TRANSPORTASI TERHADAP PENYUSUTAN BOBOT BADAN BROILER
}

\section{Supplementation of Vitamin C and Tranportation Distance to loss body weight of broiler}

\author{
Nurkholis ${ }^{1}$, Ujang Suryadi' ${ }^{1}$ Faturrahman Roni ${ }^{2}$ \\ 1Jurusan Perternakan, Politeknik Negeri Jember \\ 2Produksi Ternak, Politeknik Negeri Jember \\ Email: nur78.nk@gmail.com
}

\begin{abstract}
INTISARI
Tujuan penelitian ini adalah untuk mengetahui pengaruh suplementasi vitamin $\mathrm{C}$ dan jarak transportasi terhadap penyusutan bobot badan broiler. Metode yang digunakan dalam penelitian ini adalah metode eksperimen menggunakan broiler umur 30 hari unisexing sebanyak 128 ekor. Rancangan percobaan yang digunakan yaitu Rancangan Acak Lengkap pola Faktorial. Percobaan terdiri dari 2 faktor yaitu faktor jarak dengan 2 taraf yaitu $24 \mathrm{~km}$ (a1) dan $48 \mathrm{~km}(\mathrm{a} 2)$ dan faktor dosis vitamin C dengan 4 taraf yaitu $0 \mathrm{mg} / \mathrm{L}$ (b1), $250 \mathrm{mg} / \mathrm{L}$ (b2), 500 $\mathrm{mg} / \mathrm{L}$ (b3), dan $750 \mathrm{mg} / \mathrm{L}$ (b4). Percobaan diulang sebanyak 4 kali. Apabila diperoleh perbedaan yang nyata, maka dilanjutkan dengan uji Beda Nyata Terkecil (BNT). Suplementasi vitamin C berpengaruh nyata terhadap penyusutan bobot badan, detak jantung, glukosa darah, dan mortalitas pada broiler saat transportasi. Jarak tempuh transportasi berpengaruh nyata terhadap penyusutan bobot badan dan detak jantung pada broiler. Suplementasi vitamin $C$ dan jarak tempuh transportasi memberikan interaksi yang nyata terhadap penyusutan bobot badan, detak jantung, glukosa darah, dan mortalitas pada broiler.
\end{abstract}

Kata Kunci: Suplementasi, Vitamin C, Jarak Transportasi, Penyusutan Bobot Badan, Broiler

\begin{abstract}
The purpose of this study was to know the effect of vitamin $C$ supplementation and distance transportation on broiler weight loss. The method used in this study using 128 days of unisexing broiler. The experimental design used a Factorial Completely Randomized Design. The experimental factor consisted of 2 factors, such as the distance factor with 2 levels, $24 \mathrm{~km}$ (a1) and $48 \mathrm{~km}(\mathrm{a} 2)$, and the sumplemetation factor of vitamin $C$ with 4 levels such as $0 \mathrm{mg} / \mathrm{L}$ (b1), 250 $\mathrm{mg} / \mathrm{L} \mathrm{(b2),500} \mathrm{mg/L} \mathrm{(b3),} \mathrm{and} 750 \mathrm{mg} / \mathrm{L}$ (b4). The experiment was 4 times replication. If obtained significantly result, continued by Least Significant Difference test (LSD). Vitamin $C$ supplementation was significant to weight loss, heart rate, glucose, and mortality in broilers during transportation. The transportation mileage was significant to weight loss and heart rate in broilers. Supplementation of vitamin $C$ and transportation mileage provided a significant interaction weight loss, heart rate, glucose, and mortality in broilers.
\end{abstract}

Keywords: Supplementation, Vitamin C, Distance of Transportation, Weight Loss, Broiler

\section{PENDAHULUAN}

Usaha pengembangan peternakan saat ini menunjukkan prospek yang bagus dan mempunyai peranan penting dalam pertumbuhan ekonomi. Prospek usaha peternakan sangat terbuka lebar karena kebutuhan pangan meningkat sejalan dengan kecepatan pertumbuhan populasi manusia, seperti di Indonesia dalam 5 tahun terakhir sebesar 4,5 juta jiwa (1,49\%) per tahun. Kebutuhan pangan sektor peternakan mengalami peningkatan dari tahun 2009, 2010, 2011 berturut turut adalah 3,45\%, 
4,06\%, dan 4,23\% (Kementan, 2012). Faktor lain yang mempengaruhi pengembangan usaha peternakan yaitu produk pangan asal ternak mempunyai nilai gizi yang berkualitas.

Peternakan unggas merupakan sektor peternakan yang mengalami kemajuan pesat, diantaranya adalah ayam broiler. Menurut Sudaryani et al. (2008) broiler dapat tumbuh dengan cepat, memiliki konversi pakan yang baik, dan waktu produksinya sangat singkat, yaitu 35 sampai 40 hari. Budidaya broiler pada tahun 2008 mengalami peningkatan sebesar 8,7\% dengan tingkat konsumsi daging ayam di Indonesia yang semakin meningkat, yaitu 4,5 kg/kapita tahun 2007 menjadi 6,46 $\mathrm{kg} / \mathrm{kapita}$ tahun 2008. Hal ini membuat usaha peternakan ayam broiler menjadi usaha potensial yang menarik minat peternak untuk menjalani bisnis ini.

Transportasi merupakan kegiatan yang tidak dapat dihindarkan dalam dunia peternakan karena hal tersebut dilakukan antara lain untuk keperluan pengangkutan ke tempat pemotongan dan pemasaran. Tetapi, transportasi mempunyai efek negatif terhadap performa broiler. Transportasi dianggap sebagai stresor utama yang berdampak pada kesehatan ternak itu sendiri dan menurunkan performa produksi dengan tingginya penyusutan bobot badan.

Penyusutan bobot badan disebabkan oleh hilangnya cairan tubuh, elektrolit, dan zat nutrisi serta terganggunya keseimbangan $\mathrm{pH}$ dalam tubuh ayam. Peningakatan fungsi kardiovaskuler dan metabolisme umum merupakan penyebab dari terganggu keseimbangan cairan tubuh pada broiler. Peningkatan fungsi kardiovaskuler seperti jantung dan pembuluh darah serta metabolisme umum terjadi karena saat stress tubuh ayam merespon dengan mensekresikan kotekolamin.

Hilangnya cairan, elektrolit, zat nutrisi, dan terganggunya keseimbangan $\mathrm{pH}$ pada tubuh broler akibat transportasi akan berdampak pada penurunan bobot badan broiler. Broiler selama transportasi mengalami penurunan bobot badan mencapai 6 sampai 7\% dengan jarak perjalanan $106 \mathrm{~km}$. Tingginya penurunan bobot badan tersebut akan berdampak negatif bagi pengusaha rumah potong ayam sehingga diperlukan suatu upaya untuk meminimalkan penyusutan bobot badan selama transportasi.

Pemberian vitamin $\mathrm{C}$ terhadap broiler merupakan salah satu upaya menekan dampak negatif stress akibat transportasi, sebab menurut Pardue dan Thaxton (1985) vitamin $C$ berperan sebagai kosubtrat dalam hidroksilasi tirosin pada pelepasan norepineprin dan dalam medulla adrenalin untuk pelepasan kotekolamin lain yaitu epinefrin. Peranan ini penting untuk fungsi syaraf secara normal dan untuk kesediaan epinefrin yang berhubungan dengan stress. Kusnadi (2006) mengemukakan bahwa sublementasi vitamin C $250 \mathrm{ppm} / 3$ ekor/ hari dapat mengatasi stress akibat cekaman panas.

Vitamin C memungkinkan menjadi bahan yang dapat meminimalkan penyusutan bobot badan broiler. Penelitian tentang pemberian vitamin $\mathrm{C}$ dalam air minum sudah pernah dilakukan. Hasil penelitian yang telah dilakukan menunjukkan pemberian vitamin $\mathrm{C}$ berpengaruh terhadap konsumsi pakan dan pertambahan bobot badan. Penelitian lebih lanjut perlu dilakukan untuk mengetahui apakah vitamin $\mathrm{C}$ dapat meminimalkan penyusutan bobot badan broiler selama transportasi.

\section{MATERI DAN METODE}

Penelitian ini bersifat eksperimental dengan menggunakan broiler umur 30 hari unisexing sebanyak 128 ekor. Rancangan percobaan yang digunakan yaitu Rancangan Acak Lengkap pola Faktorial. Percobaan terdiri dari 2 faktor yaitu faktor jarak dengan 2 taraf yaitu $24 \mathrm{~km}$ (a1) dan $48 \mathrm{~km}(\mathrm{a} 2)$ dan faktor dosis vitamin $\mathrm{C}$ dengan 4 taraf yaitu 0 $\mathrm{mg} / \mathrm{L}$ (b1), $250 \mathrm{mg} / \mathrm{L} \mathrm{(b2),} 500 \mathrm{mg} / \mathrm{L}$ (b3), dan $750 \mathrm{mg} / \mathrm{L}$ (b4). Percobaan diulang sebanyak 4 kali. Apabila diperoleh perbedaan 
nyata atau sangat nyata, maka dilanjutkan dengan uji Beda Nyata Terkecil (BNT).

\section{Parameter yang Diamati}

\section{Penyusutan bobot badan}

Penyusutan bobot badan broiler diperoleh dengan mengurangi bobot badan broiler sebelum pengangkutan dengan bobot badan broiler sesudah pengangkutan. Satuan dari parameter penyusutan bobot badan adalah gram (g).

\section{Detak jantung}

Detak jantung diukur dengan menggunakan stetoskop yang ditempelkan pada bagian bawah dada broiler. Peningkatan detak jantung diperoleh dengan mengurangi detak jantung sesudah transportasi dengan detak jantung sebelum transportasi. Satuan dari parameter detak jantung adalah kali per menit (kali/menit).

\section{Kadar glukosa darah}

Pengambilan darah dilakukan sebelum pengangkutan broiler dan sesudah pengangkutan broiler. Darah diambil melalui pembuluh vena pada sayap dengan mengguanakan syringe yang steril. Sebelum pengambilan, daerah yang akan ditusuk syringe digosok dengan alkohol 70\%. Darah diambil sebanyak $3 \mathrm{ml}$ pada setiap sampel. Darah yang telah diambil selanjutnya ditempatkan pada tabung reaksi dan ditutup dengan menggunakan plastik pembungkus. Kadar glukosa darah diketahui dengan menguji sampel darah broiler dengan menggunakan alat Automatic Analyzer kimia klinik.

\section{Mortalitas}

Mortalitas ditentukan dengan menghitung jumlah ayam yang mati setelah dilakukan transportasi. Mortalitas dihitung dalam satuan persen dengan rumus seperti dibawah ini:

$$
\operatorname{Mortalitas}(\%)=\frac{\left(\text { Eayam } S b T-\sum \text { Ayam SsT }\right)}{\sum \text { Ayam SbT }} \times 100 \%
$$

Keterangan:

$S b T=$ Sebelum Transportasi

$S s T=$ Sesudah Transportasi

\section{HASIL DAN PEMBAHASAN}

Rataan hasil data setiap parameter pengamatan suplementasi vitamin $\mathrm{C}$ dan jarak tempuh saat transportasi dapat dilihat pada Tabel 4.1, Tabel 4.2, Tabel 4.3, dan Tabel 4.4.

\section{Penyusutan Bobot Badan}

Pada Tabel 4.1 dapat diketahui bahwa rataan penurunan penyusutan bobot badan tanpa suplementasi vitamin $\mathrm{C}$ memberikan hasil lebih besar dibandingkan perlakuan dengan suplemenatasi vitamin C.

Hasil sidik ragam menunjukkan bahwa suplementasi vitamin C memberikan pengaruh terhadap penurunan penyusutan bobot badan broiler. Rataan penurunan penyusutan bobot badan dengan level pemberian vitamin C sebesar $250 \mathrm{mg} / \mathrm{L}$ memberikan hasil lebih rendah dibandingkan dengan perlakuan yang lain.

Hasil sidik ragam menunjukkan bahwa faktor jarak memberikan pengaruh nyata terhadap penurunan penyusutan bobot badan broiler. Penurunan penyusutan bobot badan broiler dengan jarak tempuh $24 \mathrm{~km}$ memberikan hasil lebih rendah dibandingkan transportasi dengan jarak tempuh $48 \mathrm{~km}$.

Hasil sidik ragam menunjukkan bahwa faktor jarak tempuh dan suplementasi vitamin $\mathrm{C}$ memberikan pengaruh nyata terhadap penurunan penyusutan bobot badan broiler. Pada jarak tempuh $24 \mathrm{~km}$ dengan level suplementasi vitamin $\mathrm{C}$ sebesar 750 $\mathrm{mg} / \mathrm{L}$ memberikan penurunan penyusutan bobot badan paling rendah dibandingkan perlakuan yang lain. Sedangkan pada jarak tempuh $48 \mathrm{~km}$ dengan level suplementasi vitamin C sebesar $250 \mathrm{mg} / \mathrm{L}$ memberikan penyusutan bobot badan lebih rendah dibandingkan perlakuan yang lain.

Tabel 4.1 dapat diketahui bahwa suplementasi vitamin $\mathrm{C}$ berpengaruh 
terhadap penyusutan bobot badan broiler. Hal ini diduga pemberian vitamin $\mathrm{C}$ dapat meningkatkan resistensi terhadap panas dan menurunkan kadar hormon yang menyebabkan stres pada broiler. Menurut hasil penelitian Meade (2004) suplementasi vitamin C menurunkan kadar hormon kortikosteron dan dapat meningkatkan plasma vitamin C dalam tubuh. Anim et al. (2000) menyatakan bahwa vitamin C dapat menangkal cekaman pada ayam. Menurut Blokhina (2000) vitamin C merupakan antioksidan yang larut dalam air yang mampu meredam radikal bebas dengan cara memberikan atom hidrogen dan elektron kepada radikal bebas sehingga menghentikan atau mengurangi proses cekaman oksidatif lebih lanjut. Jarak tempuh saat transportasi memberikan pengaruh terhadap penyusutan bobot badan broiler. Menten et al. (2006) menyatakan bahwa penyusutan bobot badan dengan lama perjalanan 0 menit, 30 menit, 60 menit, 90 menit, dan 120 menit berturut turut adalah 0 g, 16,7 g, 90 g, 111,7 g, dan 106,7 g.

Hasil analisis data selisih rata-rata penyusutan bobot hidup broiler menunjukkan bahwa pemberian vitamin $\mathrm{C}$ dan jarak transportasi memberikan pengaruh berbeda nyata terhadap bobot hidup broiler $(\mathrm{P}<0.05)$. Hal ini diduga pemberian vitamin $\mathrm{C}$ dapat meningkatkan resistensi terhadap panas pada saat kondisi stres. Kondisi stres menyebabkan meningkatnya fungsi kardiovaskuler dan metabolisme umum. Peningkatan fungsi kardiovasuler dan metabolisme umum ini menybabkan hilangnya cairan tubuh, elektrolit dan zat nutrisi serta terganggunya keseimbangan $\mathrm{pH}$ dalam tubuh ayam yang berdampak pada menyusutnya bobot badan broiler. Stres menyebabkan terjadinya perubahan penggunaan vitamin $\mathrm{C}$ sehingga terjadi defisiensi vitamin C (Habibie, 2010). Vitamin $C$ berperan sebagai kosubstrat dalam hidroksilasi tirosin pada pelepasan norepineprin dan dalam medulla adrenalin untuk pelepasankotekolamin lain yaitu epinefrin yang berhubungan dengan stres (Pardue dan Thaxton, 1985). Vitamin C dapat menurunkan rasio heterophil lymphocyte dan plasma kortikosteron yang berhubungan dengan stres baik saat pemanenan maupun transportasi (Zulkifli et al., 2000).

Tabel 4.1 Rataan selisih bobot badan broiler sebelum dan sesudah transportasi (g)

\begin{tabular}{|c|c|c|c|c|c|}
\hline \multirow[b]{2}{*}{ Jarak } & \multicolumn{5}{|c|}{ Level } \\
\hline & $\begin{array}{c}0 \mathrm{mg} / \mathrm{L} \\
\text { (B1) }\end{array}$ & $\begin{array}{c}250 \mathrm{mg} / \mathrm{L} \\
\text { (B2) }\end{array}$ & $\begin{array}{c}500 \mathrm{mg} / \mathrm{L} \\
\text { (B3) }\end{array}$ & $\begin{array}{c}750 \mathrm{mg} / \mathrm{L} \\
\text { (B4) }\end{array}$ & Rataan \\
\hline 24 km (A1) & $50^{\mathrm{cd}}$ & $40^{\mathrm{bc}}$ & $37,5^{\mathrm{ab}}$ & $35^{\mathrm{a}}$ & $40,625^{a}$ \\
\hline 48 km (A2) & $90 \mathrm{~g}$ & $60^{\mathrm{d}}$ & $77,5^{\text {ef }}$ & $80^{\mathrm{fg}}$ & $76,875^{b}$ \\
\hline Rataan & $70^{c}$ & $50^{a}$ & $57,5^{\mathrm{ab}}$ & $57,5^{b}$ & \\
\hline
\end{tabular}

\section{Detak Jantung}

Tabel 4.2 menunjukkan bahwa rataan detak jantung tanpa suplementasi vitamin $\mathrm{C}$ memberikan hasil lebih besar dibandingkan perlakuan dengan suplementasi vitamin C. Hasil sidik ragam menunjukkan bahwa faktor suplementasi vitamin $\mathrm{C}$ memberikan pengaruh nyata $(\mathrm{P}<0,05)$ dalam menurunkan peningkatan detak jantung broiler. Rataan detak jantung tanpa suplementasi vitamin $\mathrm{C}$ memberikan hasil lebih besar dibandingkan dengan perlakuan yang lain. Rataan detak jantung dengan level suplementasi vitamin $C$ sebesar $250 \mathrm{mg} / \mathrm{L}$ dan $750 \mathrm{mg} / \mathrm{L}$ memberikan hasil lebih rendah dibandingkan dengan perlakuan yang lain. Hasil sidik ragam menunjukkan bahwa faktor jarak memberikan pengaruh nyata $(\mathrm{P}<0,05)$ terhadap peningkatan detak jantung broiler. Detak jantung broiler dengan jarak tempuh 
$24 \mathrm{~km}$ memberikan hasil yang lebih rendah dibandingkan transportasi dengan jarak tempuh $48 \mathrm{~km}$. Hasil sidik ragam menunjukkan bahwa faktor jarak tempuh dan suplementasi vitamin $\mathrm{C}$ memberikan pengaruh nyata $(\mathrm{P}<0,05)$ dalam menurunkan detak jantung broiler. Jarak tempuh $24 \mathrm{~km}$ dengan level suplementasi vitamin $C$ sebesar
$250 \mathrm{mg} / \mathrm{L}$ dan $500 \mathrm{mg} / \mathrm{L}$ memberikan peningkatan detak jantung lebih rendah dibandingkan perlakuan yang lain. Sedangkan pada jarak tempuh $48 \mathrm{~km}$ dengan level suplementasi vitamin C sebesar $750 \mathrm{mg} / \mathrm{L}$ memberikan peningkatan detak jantung lebih rendah dibandingkan dengan perlakuan yang lain.

Tabel 4.2 Rataan selisih detak jantung broiler sebelum dan sesudah transportasi (detak/menit)

\begin{tabular}{|c|c|c|c|c|c|}
\hline \multirow[b]{2}{*}{ Jarak } & \multicolumn{5}{|c|}{ Level } \\
\hline & $\begin{array}{c}0 \mathrm{mg} / \mathrm{L} \\
\text { (B1) }\end{array}$ & $\begin{array}{c}250 \mathrm{mg} / \mathrm{L} \\
\text { (B2) }\end{array}$ & $\begin{array}{c}500 \mathrm{mg} / \mathrm{L} \\
\text { (B3) }\end{array}$ & $\begin{array}{c}750 \mathrm{mg} / \mathrm{L} \\
\text { (B4) }\end{array}$ & Rataan \\
\hline $24 \mathrm{~km}$ (A1) & $30^{\text {ef }}$ & $10^{\mathrm{a}}$ & $10^{\mathrm{ab}}$ & $17 \mathrm{bc}$ & $16,75^{\mathrm{a}}$ \\
\hline $48 \mathrm{~km}(\mathrm{~A} 2)$ & $40 \mathrm{~g}$ & $29 \mathrm{de}$ & $30^{\mathrm{f}}$ & $22^{d}$ & $30,25^{b}$ \\
\hline Rataan & $35^{c}$ & $19,5^{a}$ & $20^{a b}$ & $19,5^{\mathrm{ab}}$ & \\
\hline
\end{tabular}

Tabel 4.2 menunjukkan suplementasi vitamin $\mathrm{C}$ berpengaruh dalam menurunkan detak jantung broiler. Hal ini diduga vitamin $\mathrm{C}$ berperan dalam produksi hormon epinefrin dan norepinefrin. Selama mengalami stres tubuh akan mengaktivasi hipotalamus yang selanjutnya akan mengendalikan sistem syaraf simpatis. Menurut Susalit et al. (2001) melalui syaraf simpatis tekanan darah akan meningkat secara intermiten karena penyempitan pembuluh darah yang akan mengakibatkan detak jantung lebih cepat. Hal ini disebabkan sistem syaraf simpatis memberi sinyal kepada medulla adrenalin untuk melepaskan hormon epinefrin dan norepinefrin, selanjutnya kedua hormon ini mempengaruhi pelepasan ion dalam tubuh. Jarak tempuh transportasi juga berpengaruh terhadap peningkatan detak jantung. Jarak tempuh yang jauh mengakibatkan broiler mengalami stres sehingga tubuh lebih banyak mengeluarkan hormon epinefrin dan norepinefrin yang akan mempengaruhi frekuensi detak jantung broiler.

Hasil analisis data menunjukkan bahwa pemberian vitamin $\mathrm{C}$ dan jarak transportasi memberikan pengaruh berbeda nyata dalam menurunkan detak jantung broiler $(\mathrm{P}<0,05)$. Kecepatan detak jantung mengalami peningkatan yang diduga karena selama stres tubuh akan mengaktivasi hipotalamus yang selanjutnya akan mengendalikan dua sistem neuroendokrin yaitu sistem syaraf simpatis dan korteks adrenal. Sistem syaraf simpatis juga memberi sinyal kepada medulla adrenal untuk melepaskan epinefrin dan norepinefrin ke aliran darah (Elrom, 2000). Hal tersebut menciptakan efek depolarisasi yang menyebabkan detak jantung yang lebih cepat.

Tabel 4.3 Rataan selisih kadar glukosa darah broiler sebelum dan sesudah transportasi (mg/L)

\begin{tabular}{|c|c|c|c|c|c|}
\hline \multirow[b]{2}{*}{ Jarak } & \multicolumn{5}{|c|}{ Level } \\
\hline & $\begin{array}{c}0 \mathrm{mg} / \mathrm{L} \\
\text { (B1) }\end{array}$ & $\begin{array}{c}250 \mathrm{mg} / \mathrm{L} \\
\text { (B2) }\end{array}$ & $\begin{array}{c}500 \mathrm{mg} / \mathrm{L} \\
\text { (B3) }\end{array}$ & $\begin{array}{c}750 \mathrm{mg} / \mathrm{L} \\
\text { (B4) }\end{array}$ & Rataan \\
\hline $24 \mathrm{~km}$ (A1) & $10,75^{\text {cd }}$ & $10,25^{\mathrm{a}}$ & $10,25^{\mathrm{ab}}$ & $10,5^{b c}$ & $14,437 \mathrm{a}$ \\
\hline $48 \mathrm{~km}(\mathrm{~A} 2)$ & $21,5 \mathrm{~g}$ & $12,5 \mathrm{de}$ & $13,25^{\mathrm{ef}}$ & $14,25^{\mathrm{f}}$ & $15,375^{\mathrm{ab}}$ \\
\hline Rataan & $16,125^{\mathrm{d}}$ & $11,375^{\mathrm{a}}$ & $11,75^{\mathrm{ab}}$ & $12,375^{b c}$ & \\
\hline
\end{tabular}




\section{Glukosa Darah}

Tabel 4.3 dapat diketahui bahwa rataan kadar glukosa darah tanpa suplementasi vitamin C memberikan hasil lebih besar dibandingkan perlakuan dengan suplementasi vitamin C. Hasil sidik ragam menunjukkan bahwa pemberian vitamin $\mathrm{C}$ memberikan pengaruh nyata $(\mathrm{P}<0,05)$ dalam menurunkan kadar glukosa darah broiler. Rataan kadar glukosa darah dengan level suplementasi vitamin C sebesar $250 \mathrm{mg} / \mathrm{L}, 500 \mathrm{mg} / \mathrm{L}$, dan $750 \mathrm{mg} / \mathrm{L}$ memberikan hasil lebih rendah dibandingkan dengan perlakuan tanpa suplementasi vitamin $\mathrm{C}$.

Hasil sidik ragam menunjukkan bahwa faktor jarak tempuh $24 \mathrm{~km}$ maupun $48 \mathrm{~km}$ memberikan pengaruh tidak berbeda nyata terhadap glukosa broiler, tetapi kadar glukosa darah broiler pada jarak $48 \mathrm{~km}$ lebih besar daripada $24 \mathrm{~km}$. Hasil sidik ragam menunjukkan bahwa faktor jarak tempuh dan suplementasi vitamin C memberikan pengaruh nyata dalam menurunkan glukosa darah broiler. Pada jarak tempuh $24 \mathrm{~km}$ dengan level suplementasi vitamin $C$ sebesar $250 \mathrm{mg} / \mathrm{L}$ dan $500 \mathrm{mg} / \mathrm{L}$ memberikan peningkatan glukosa darah lebih rendah dibandingkan perlakuan yang lain. Jarak tempuh $48 \mathrm{~km}$ dengan level suplementasi vitamin C sebesar $250 \mathrm{mg} / \mathrm{L}$ memberikan peningkatan glukosa darah lebih rendah dibandingkan perlakuan yang lain.

Hasil analisis data glukosa darah menunjukkan bahwa suplementasi vitamin $\mathrm{C}$ dan jarak transportasi memberikan pengaruh nyata dalam menurunkan glukosa darah dalam broiler $(\mathrm{P}<0,05)$. Hal ini diduga vitamin $\mathrm{C}$ berpengaruh terhadap produksi hormon epinefrin dan norepinefrin serta glukokortikoid. Menurut Sari (2007) stres mengakibatkan tubuh mensekresikan hormon epinefrin. Stres saat transportasi menyebabkan kadar glukosa dalam darah meningkat. Epinefrin dapat menghalangi pelepasan insulin sebab epineprin menimbulkan glikogenolisis pada sel hepar serta otot karena stimulasi enzim fosforilase.
Insulin mempunyai fungsi untuk menurunkan kadar glukosa dalam darah. Hal ini sesuai dengan Bawono (2012) yang menyatakan bahwa insulin dapat menurunkan kadar glukosa, asam lemak, dan asam amino dalam darah serta mendorong penyimpanan zat-zat gizi tersebut. Stres yang terus menerus akibat stesor transportasi menyebabkan tubuh mensekresikan glukokortikoid yang dihasilkan oleh ATCH yang berperan dalam gluconeogenesis sehingga meningkatkan glukosa darah melalui peningkatan katabolisme protein di jaringan, peningkatan pengambilan asam amino oleh hepar, peningkatan aktivitas enzim transaminase, dan enzim lain yang berhubungan dengan gluconeogenesis di hepar (Sari, 2007).

\section{Mortalitas}

Mortalitas broiler pada penelitian suplementasi vitamin $\mathrm{C}$ dan jarak transportasi terhadap bobot hidup broiler saat transportasi sebesar $0 \%$ pada setiap perlakuan. Gross (1998) menjelaskan bahwa kematian unggas akibat cekaman panas tanpa suplementasi vitamin C sebesar 40\%, selanjuttnya suplementasi vitamin C $220 \mathrm{ppm}$, 330 ppm, 660 ppm, dan 1.100 ppm berturut turut adalah $12 \%, 0 \%, 31 \%$, dan $15 \%$. Persentase kematian broiler dipengaruhi oleh jarak` pada saat tranportasi. Pada penelitian Axelord dan Reisine (1984) level hormon ACTH yang dikenal sebagai faktor penting dalam respon endokrin saat stres akan meningkat pada jarak 100 dan $200 \mathrm{~km}$, lebih lanjut, peningkatan hormon ACTH akan mempengaruhi produksi hormon kortisol yang merupakan bagian dari glukokortikoid. Efek dari atrofi organ-organ kekebalan tersebut adalah kematian pada ternak.

\section{KESIMPULAN}

Suplementasi vitamin C berpengaruh nyata terhadap penyusutan bobot badan, detak jantung, glukosa darah, dan mortalitas pada broiler saat transportasi. Jarak tempuh 
transportasi berpengaruh nyata terhadap penyusutan bobot badan dan detak jantung pada broiler. Suplementasi vitamin C dan jarak tempuh transportasi memberikan interaksi yang nyata terhadap penyusutan bobot badan, detak jantung, glukosa darah, dan mortalitas pada broiler.

\section{DAFTAR PUSTAKA}

Anim, A.J., T.L. Lin, P.Y. Hester, D. Thiagarajan, B.A. Watkins, and C.C. Wu. 2000. Ascorbic acid supplementation improved antibody response to infectious bursal disease vaccination in chickens. Poultry Science. 79(5): 680688.

Axelord, J. and T.D. Reisine. 1984. Stress Hormones: Their interaction and regulation. Science. 224(4648): 452459.

Bawono, M.N. 2012. Kontrol Hormon Insulin dan Glukagon dalam Perubahan Metabolisme Selama Latihan. https://anzdoc.com/kontrol-hormoninsulin-dan-glukagon-dalamperubahan-metaboli.html. Diakses tanggal 14 September 2018.

Bayliss, P.A. and M.H. Hinton, 1990. Transportation of broilers with special reference to mortality rates. Applied Animal Behavior Science. 28(1-2): 93118.

Blokhina, 0. 2000. Anoxia and Oxidative Stress: Lipid Perodaxtion, Mitochondrial Funcionts in Plants Antioxidant Status and Mitochondrial Funcions in Plants. http://ethesis,helsinki.fi/julkaisut/mat /bioti/vk/bilokhina/anoxiaan.html. Diakses tanggal 17 September 2018.

Elrom, K. 2000. Handling and transportation of broiler welfare, sterss, fear and meat quality. Israel Journal of Veterinary Medicine. 56 (1).

Gross, W.B. 1988. Effect ascorbic acid on the mortalily of leghorn-type chickens due to overheating. Avian Disease. 32(3): 561-566.

Habibie, A. 2010. Pengaruh cekaman panas terhadap kebutuhan vitamin C pada ayam petelur komersial yang sedang bereproduksi. Skripsi. Institut Pertanian Bogor. Bogor.

Kementerian Pertanian. 2012. Laporan Kinerja Kementerian Pertanian Tahun 2011.

http://sakip.pertanian.go.id/admin/da ta2/laporan\%20kinerja\%20kementan \%202017.pdf. Diakses tanggal 1 September 2018.

Kusnadi, E. 2006. Suplementasi vitamin C sebagai penangkal cekaman panas pada ayam broiler. Jurnal Ilmu Ternak dan Veteriner. 11(4): 249-253.

Meade, S.M. 2004. The effect of social stress and vitamin $\mathrm{C}$ on immunity and response to vaccination with hemmorrhagic enteritis virus in turkeys. Dissertation. Faculty of Virginia Polytechnic Institute and State University. Blacksburg. Virginia.

Menten, J.F.M, J.A.D.B. Filho, M.A.N. Silva, I.J.O. Silva, A.M.C. Racanicci, A.A.D. Coelho, and V.J.M. Savino. 2006. Physiological Response of Broiler Chickens to Preslaughter Heat Stress. University of Sao Paulo, Escola Superior de Agriculture Luiz de Queiroz, Caixa Postal 9, 13418-900 Piracicaba, SP, Brazil.

Pardue, S.L, and J.P. Thaxson. 1985. Ascorbic Acid in Poultry: A Review. World's Poultry Science Journal. 42(2): 107123.

Sari, M.I., 2007. Reaksi-Reaksi Kimia sebagai Sumber Glukosa Darah. http://repository.usu.ac.id/bitstream/ handle/123456789/1934/09E01867.p df? sequence $=1$ \&isAllowed $=y$. Diakses tanggal 20 Agustus 2018.

Sudaryani, T., H. Santosa, dan U.H. Tanuwiria. 2011. Stategi Eliminasi Stres Transportasi pada Sapi Potong Menggunakan Kromium Organik. UNPAD Press. Bandung.

Susalit, E., J.E Kapojos, dan H.R Lubis. 2001. Buku Ajar Ilmu Penyakit Dalam II. Balai penerbit FKUI. Jakarta.

Zulkifli, I., M.T.C. Norma, C.H. Chong, and T.C. Loh. 2000. Heterophil lymphocyte ratio and tonic immobility reactions to preslaughter handling in broiler chickens treated with ascorbid acid. Poultry Science. 79(3). 